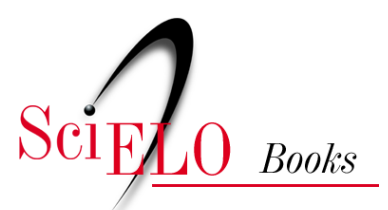

\title{
Capítulo 1. Cidades novas e o desejo
}

\author{
Ricardo Trevisan
}

\section{SciELO Books / SciELO Livros / SciELO Libros}

TREVISA, R. Cidades novas e o desejo. In: Cidades novas [online]. Brasília: Editora UnB, 2020, pp. 103-128. Pesquisa, inovação \& ousadia series. ISBN: 978-65-5846-158-6. https://doi.org/10.7476/9786558461586.0006.

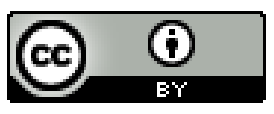

All the contents of this work, except where otherwise noted, is licensed under a $\underline{\text { Creative }}$ Commons Attribution 4.0 International license.

Todo o conteúdo deste trabalho, exceto quando houver ressalva, é publicado sob a licença Creative Commons Atribição 4.0.

Todo el contenido de esta obra, excepto donde se indique lo contrario, está bajo licencia de la licencia Creative Commons Reconocimento 4.0. 


\section{Cidades novas e o desejo}

Primeira parada: alguma cidade no interior do estado de São Paulo, com baldeação para o norte paranaense.

A Paulista, da Companhia Paulista de Estradas de Ferro (1872); a Mogiana, da Companhia Mogiana de Estradas de Ferro (1872); a Sorocabana, da Estrada de Ferro Sorocabana (1875); a Araraquarense, da Estrada de Ferro Araraquarense (1895); a Noroeste, da Estrada de Ferro Noroeste do Brasil (1905), e respectivos entroncamentos, como Ourinhos-Umuarama no Paraná (1920) - seja qual for a ferrovia escolhida, esteja preparado para encontrar dezenas de CNs.

Implantada a partir da capital paulista, ultrapassando os limites administrativos conforme a expansão de sua franja, essa malha ferroviária mimetiza-se em um processo inédito de urbanização da hinterlândia - um território até então pouco explorado, coberto pela Mata Atlântica e povoado por tribos indígenas (ANDRADE, 1945). Uma urbanização construída pela criação de novos núcleos, empreendidos pelo desejo do poder público ou da iniciativa privada. Obras intencionadas, visando a subsidiar a economia do café no último quarto do século XIX e, simultaneamente, a respaldar o processo de colonização e ocupação de novas fronteiras durante o século XX.

Originária do Rio de Janeiro - início do século XIX -, a cafeicultura teve o estado de São Paulo como palco principal para o seu desenvolvimento. O cultivo do café em solo paulista partiu da divisa com o Rio de Janeiro, passando pelo Vale do Paraíba e avançando para o oeste (década de 1860) - rumo às terras virgens do planalto -, chegando ao norte do Paraná, sul de Goiás e do Mato Grosso já no século XX. 
Esse modelo de economia agroexportadora, ${ }^{1}$ diferentemente dos anteriores (exploração da cana-de-açúcar, de minério e mesmo borracha), que utilizavam as cidades apenas como entrepostos de suas produções, introduziu novos aspectos no cenário produtivo nacional. Apesar de basear-se na zona rural, a cafeicultura proporcionou a origem de uma nova relação entre campo e cidade (SINGER, 1973; CANO; 1998). Para se tornar produtiva, a lavoura de café necessitava de um período de cinco a seis anos de espera - período que o produtor passava sem obter retorno lucrativo -, ao mesmo tempo em que precisava de capital para abrir novos cafezais. Como solução, obrigava-se a fazer empréstimos e financiamentos de capital - inexistentes no país na quantidade necessária - diretamente com bancos estrangeiros, principalmente ingleses, que começavam a instalar filiais na capital da província.

Esta nova relação campo-cidade ainda era fomentada por uma reversão dos lucros, obtidos pela oligarquia agrária no campo, em melhorias urbanas - portos, armazéns, transportes e comunicações bem como aquelas inerentes à própria urbanização -, em virtude da necessidade do produtor de utilizar também o espaço urbano para que o beneficiamento - modo de produção mecanizado - do café ocorresse, gerando novas ofertas de emprego e incentivando novas técnicas produtivas.

Além disso, a cafeicultura também corroborou, no estado de São Paulo e em estados vizinhos, o surgimento de uma coesa malha de ferrovias que ligava as zonas produtivas às principais cidades do estado, patrocinada não apenas pelo poder público, mas pelos ricos fazendeiros (CANO, 1998). De um lado, a modernização dos meios de transportes em solo paulista permitiu, num primeiro momento, a redução de custos com o escoamento da produção desde a lavoura até o porto de Santos, e, num segundo momento, a criação de uma densa rede urbana, formada por dezenas de CNs surgidas a partir de cada ponto de parada do trem (MONBEIG, 1984).

1 Resumidamente, compunham o complexo cafeeiro: a atividade produtora de café; a agricultura produtora de alimentos e matéria-prima (para subsistência ou comércio); a atividade industrial (produção de equipamentos de beneficiamento de café visando ao aumento da produtividade); indústria de sacarias de juta (para embalagem do café e demais compartimentos produtivos da indústria); a implantação e desenvolvimento do sistema ferroviário (reduzir custos com transporte); a expansão do sistema bancário (financiamentos); e a atividade do comércio com importação e exportação (CANO, 1998). 
Embora não tenha financiado diretamente as ferrovias, o poder público lançou ações paralelas que corroboraram a transformação urbana dessa região. O governo paulista, por exemplo, foi responsável pelo financiamento subsidiado imigratório, permitindo a entrada de 1,2 milhões de pessoas no estado, como também tomou a iniciativa de instituir "núcleos coloniais de imigrantes" para a agricultura de subsistência e de distribuir glebas de terras devolutas (no sertão ocidental paulista) para a expansão cafeeira, afirmando a importância do campo na economia estadual e nacional (CANO, 1998).

O objetivo do poder público era criar mecanismos de distribuição do contingente populacional, excedente na capital paulista, pelo interior. Nesse sentido, Maria Alice Rosa Ribeiro (1991), em História sem fim: inventário da saúde pública - São Paulo 1880-1930, relata um breve caso de manipulação da massa operária frente aos interesses públicos:

O DET [Departamento Estadual de Trabalho] e a Comissão de Socorros propuseram o combate ao "pernicioso urbanismo" através da concessão de todas as facilidades para os desempregados que se dispuseram a ir procurar emprego no interior. Desurbanizar a Capital, levar a massa de ociosos para o interior foi a medida tomada sob o comando do DET e do seu órgão, especialmente voltado para a questão do mercado de trabalho - a Agência Oficial de Colocação. Cartazes anunciando as facilidades e as concessões dadas pelo governo foram espalhados em diversos pontos de concentração de imigrantes e de desempregados. (RIBEIRO, 1991, p. 181-182).

Esse caráter antiurbanista, indicado pela autora como recorrente já na década de 1910, seria retomado no governo de Getúlio Vargas, durante o Estado Novo (19371945), pelo programa “Marcha para o Oeste” (1938). O slogan nacionalista, mais do que expressar a tomada do continente mediante sua ocupação e colonização, 
permitia ao governo aliviar as tensões e os conflitos sociais existentes nas grandes cidades. Para o Estado, a criação de CNs incentivaria ou instigaria o imaginativo dos mais aflitos a começar uma nova vida, teoricamente em melhores condições.

Com a derrocada do café nos anos 1920, o impulso à industrialização e, consequentemente, à urbanização alinhava-se ao empenho governamental em promover a interiorização do país e em reforçar as defesas de nossas fronteiras, como o próprio presidente Vargas afirmou na época:

[...] a civilização brasileira, à mercê dos fatores geológicos, estendeu-se no sentido da longitude, ocupando o vasto litoral, onde se localizavam os centros principais de atividade, riqueza e vida. Mais do que uma simples imagem, é uma realidade urgente e necessária galgar a montanha, transpor os planaltos e expandir-nos no sentido das latitudes. Retomando a trilha dos pioneiros que plantaram no coração do Continente, em vigorosa e épica arremetida, os marcos das fronteiras territoriais, precisamos de novo suprimir os obstáculos, encurtar as distâncias, abrir e estender as fronteiras econômicas, consolidando, definitivamente, os alicerces da nação.

O verdadeiro sentido de brasilidade é a marcha para o Oeste. No século XVII, de lá jorrou o caudal de ouro que transbordou na Europa e fez da América o Continente das cobiças e tentativas aventurosas. E lá teremos de ir buscar: dos vales férteis e vastos, o produto das culturas variadas e fartas; das entranhas da terra, o metal com que forjar os instrumentos de nossa defesa e do nosso progresso industrial [...]. (apud NEIVA, 1942, s.p.).

Com essa iniciativa de colonizar regiões com baixíssima taxa de ocupação e expandir internamente o mercado econômico do país, o propósito do governo 
Vargas era iniciar um processo de inversão na relação de dependência entre campo e cidade. O modelo econômico nacional, baseado tradicionalmente na monocultura agroexportadora, cedia espaço para um novo e mais atraente: o industrial. Dessa forma, a importância do meio rural enquanto espaço do processo de produção retraía, ao mesmo tempo em que a importância do meio urbano, devido à estrutura do processo industrial, se expandia de forma acelerada. A instalação de uma rede urbana - inexistente até então - propiciaria espaço físico para a implantação de indústrias, criaria um mercado consumidor para os produtos fabricados nos grandes centros industriais, além de servir de entreposto e de fornecedora dos produtos agropecuários - matéria-prima para as indústrias - cultivados na zona rural.

Territorialmente, o país não apresentava uma ocupação homogênea. Por questões político-econômicas, a urbanização brasileira, até o século XIX, foi contida em sua linha litorânea, sendo insignificantes as exceções: algumas vilas pombalinas e outras geradas ao longo do ciclo mineral no século XVIII (MARX, 1980). O restante do país se encontrava intocado e com suas divisas desprotegidas em relação aos países limítrofes à sua face oeste. Ocupar o interior, rumo ao ocidente, facilitaria ao governo se apossar de seu território como um todo e garantir tanto a proteção do espaço nacional quanto expandir a rede urbana.

A rede ferroviária, nascida com a cultura do café, passaria agora a contribuir no processo de ocupação do território. Ao longo das linhas férreas, companhias privadas - retalhadoras de terras - ou os donos de imensas glebas loteavam suas terras e as vendiam aos "pioneiros” que vinham do Leste (MONBEIG, 1984). Áreas antes cobertas por florestas cederam lugar à lavoura e à criação de gado, na época presentes em fazendas, sítios e chácaras, atendendo às necessidades do mercado nacional e internacional e contribuindo para a economia estadual. Assim, simultaneamente à introdução da ferrovia e à ocupação de áreas rurais, começaram a despontar cidades como centros de apoio à população residente na região. Núcleos urbanos regularmente implantados, como descreve Murillo Marx em seu livro Cidade brasileira (1980): 
A vigorosa marcha dos cafezais para o oeste promove centenas de novas fundações em São Paulo, Paraná e Minas. As matas virgens cedem lugar a fazendas e povoados. Uns e outros vão retalhar a terra roxa, tendo em vista as peculiaridades geográficas e as vantagens da comercialização das glebas e dos lotes urbanos. O tipo de sítio disponível, numa paisagem muito homogênea, o trem, novo meio de transporte com suas exigências de trajeto, e a rápida divisão e venda dos terrenos geram uma cena urbana nova, monotonamente repetida e regular. (MARX, 1980, p. 36)

Figura 6: Andradina

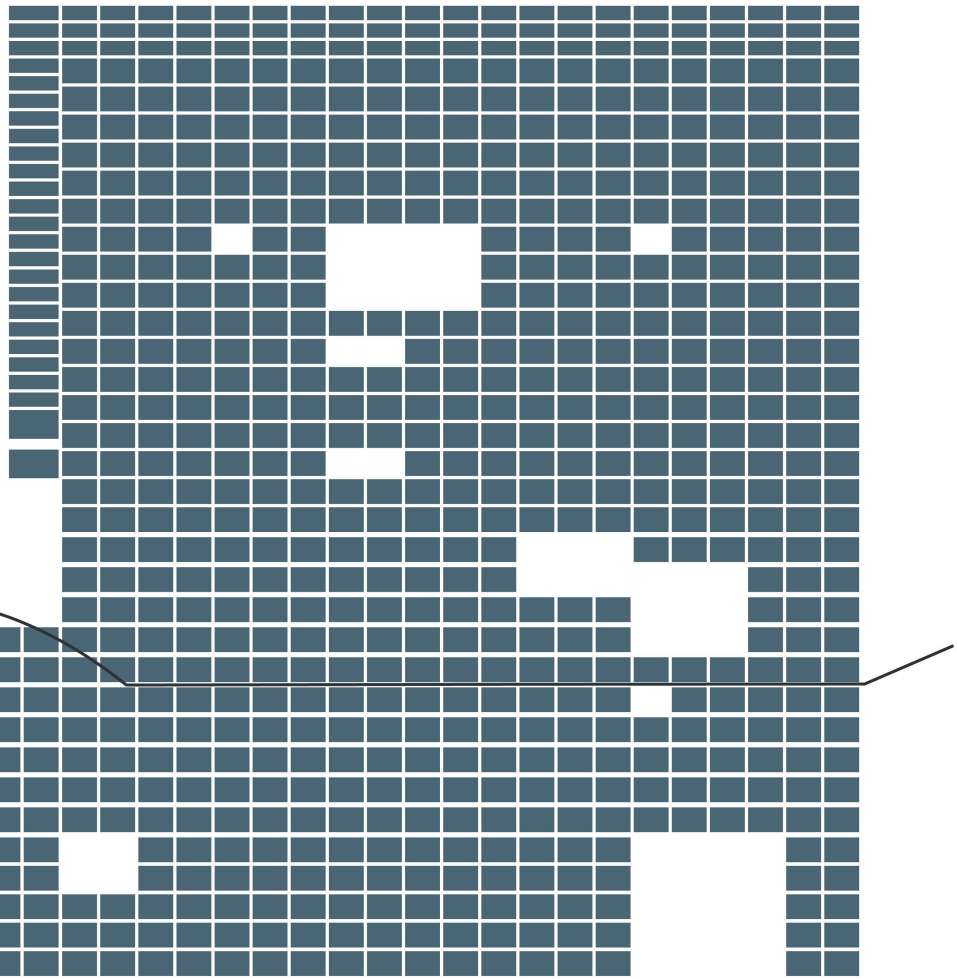


Urbanisticamente e diferentemente dos tipos embelezador e de melhoramentos que vinham sendo praticados nos grandes centros urbanos do país, o traçado dessas cidades de colonização e expansão territorial apresentava a regularidade e a homogeneidade como marcas (BRUAND, 1991), principalmente devido ao sítio plano e à rapidez necessária para sua implementação, como sucedido nas paulistas: Franca (1921), Jales (1928), Tupã (1929), Andradina (1932), Adamantina (1939), além de Londrina (1929) e Arapongas (1935) no estado do Paraná. Traçados que se contrapunham a alguns tipos dotados de projetos urbanísticos mais apurados com adequação ao sítio, arborização, zoneamento complexo, saneamento etc. -, como Luiziânia (1941) e Panorama (1952) em território paulista, e Maringá (1945) e Cianorte (1955) em terras paranaenses. No conjunto, eram CNs projetadas por topógrafos, agrimensores, engenheiros e/ou arquitetos, financiadas por companhias privadas ou iniciativas individuais com o intuito de especular a terra agrícola.

Exemplo disso foi a ação empreendedora da Companhia de Terras Norte do Paraná - de capital inglês -, que assentou linhas de transporte e negociou terras no seu trajeto, planejando localidades com zonas suburbanas e cinturões verdes a cada 15 ou 12 quilômetros sobre a ferrovia (REGO, 2009). Tal planejamento, a partir de 1925, contava com um plano específico de divisão das CNs em três graus de importância e tamanho, como aponta Rosana Steinke (2002, p. 214):

As maiores eram denominadas cidades-polo, distribuídas a cada 100 quilômetros umas das outras e previstas para comportar um número maior de habitantes, ainda que não obrigatoriamente o mesmo para todas, sendo que algumas tinham a previsão de até 200 mil pessoas. Estas deveriam ter uma rede de comércio e serviços bem estruturada, capaz de atender a toda a região por ela compreendida. A segunda categoria de cidades novas era formada por núcleos urbanos de tamanho médio, com comércio de menor porte e alguns serviços mais restritos, podendo abrigar um número 
entre 10 mil e 20 mil habitantes. A terceira forma de assentamento criada tinha uma população bem menor, em torno de 5 mil habitantes, denominado de "patrimônio", formando a última tipologia de uma rede hierarquizada.

A regularidade dessas cidades dispostas ao longo da linha férrea permite-nos fazer um paralelo com o tipo de Cidade Linear $^{2}$ do espanhol Arturo Soria y Mata (1844-1920). Em ambos os casos, é possível verificar a presença da ferrovia como elemento estruturador da escala urbana e regional. Se, no caso espanhol, a ideia de expansão urbana foi trabalhada via linha férrea interligando duas cidades existentes, nas CNs do oeste paulista e norte paranaense a implantação de cada cidade era gerenciada pela ferrovia e suas estações - quase sempre equidistantes uma das outras. Do mesmo modo, podem-se fazer relações dessa produção urbanística com o tipo de rede de cidades apresentadas por Ebenezer Howard em sua cidade-jardim (1898) como forma de expansão urbana e distribuição populacional mediante a inserção de um novo núcleo - superando em três décadas as cidades-satélites de Londres -; ou com o Movimento Americano Anti-urbanista, em que o arquiteto-protagonista Frank Lloyd Wright (1867-1959) apresentou a negação da cidade mediante a interiorização dos Estados Unidos da América pela divisão do território em inúmeras propriedades rurais abastecidas por autovias ou pelo transporte aéreo individual.

Urbanização linear pelas ferrovias, cidades-satélites da capital paulista, tipo antiurbanista, ou mesmo um planejamento regional, como defendia Patrick Geddes (1854-1932) em sua obra Cidades em evolução de 1915. Seja qual for sua caracterização e aproximação teórica, o processo de ocupação e urbanização dessa região, iniciado nas primeiras décadas do século XX e intensificado entre os anos 1930

2 No ano de 1882, em artigo publicado pelo jornal de Madri El Progresso, Soria y Mata divulgou seus ensaios para a criação de uma cidade ideal: a Cidade Linear. A proposta referia-se à distribuição de um assentamento ao longo de uma linha desenhada acompanhando o sistema de circulação adotado:o transporte ferroviário. A cidade se estruturaria a partir da linha férrea, crescendo linearmente sem limites e de forma organizada, sendo uma resposta à expansão irregular das cidades existentes e um modo de não desconfigurar ou destruir os centros históricos das grandes cidades. 
e 1950, gerou dezenas e dezenas de CNs. Esse, um processo resumido por Pierre Monbeig (1984, p. 23) no seguinte relato:

Tudo se passa como se este país conhecesse em 75 anos, um século no máximo, o que se levou milênios para fazer na Europa. E certamente é isto: nascimento e formação da paisagem rural, fundação e crescimento das cidades, construção duma rede de comunicações, mistura de raças, elaboração de uma mentalidade regional.

CNs fundadas no interior dos estados de São Paulo e Paraná, intencionadas pelo desejo do poder público ou pela iniciativa privada, para auxiliar na produção cafeeira ou na ocupação de terras ermas, estrategicamente posicionadas ao longo das linhas férreas, traçadas por técnicos e/ou graduados num curto período da história de nosso país. CNs não integralmente exibidas, mas contextualizadas a fim de revelar o primeiro segmento de seu DNA: o desejo.

Tanto governos estaduais como federal administraram as ações que confluíram para o estabelecimento de tal cenário urbano. Uma postura empreendedora fomentada por ações privadas - fossem coletivas, fossem individuais -, economicamente ativas, que viram na criação de CNs a oportunidade de expandir seus investimentos, aplicando capital excedente, e de obter lucros antes inimagináveis. Um simples retrato da necessidade da figura empreendedora na concepção das CNs.

\subsection{Empreendedores}

Se as CNs têm genitores, estes são seus empreendedores. Enganados estamos ao acreditar que os pais das CNs são seus projetistas (arquitetos, engenheiros, topógrafos etc.), coadjuvantes no processo de construção de uma nova cidade. Os verdadeiros protagonistas são aqueles agentes detentores do desejo, da intenção, da ideia inicial em criá-las. As CNs tornam-se crias não do acaso, mas de um querer; nascem em virtude 
do interesse e da vontade de um indivíduo ou de um grupo deles que, possuidores de capital público ou privado, conseguirão empreender sua construção.

Todos os predicados utilizados para relacionar criador e cria remetem-nos a uma aspiração humana diante de algo esperado. Nesse sentido, as CNs correspondem aos anseios de seus idealizadores, são a materialização de um desígnio, seja ele a representação física do poder, a constituição de uma fonte lucrativa ou a solução para um determinado problema.

As CNs são, a seu título, o equivalente da visão espacial dos projetos dos Estados e dos projetos de uma sociedade. Além de refletir as ideologias do momento, revelam os protagonistas do projeto, geralmente monarcas e chefes de Estado, comunidades locais organizadas, grupos ou indivíduos portadores de uma utopia ou por necessidade.

Para alguns autores, como Nadir Boumaza et al. (2006, p. 523, tradução nossa), ${ }^{3}$ os projetos de CNs não passam de uma "marca da ação de poder e coletividade desde a antiguidade traduzindo o desejo dos homens de fabricar eles mesmos sua cidade à maneira de seus ideais e fantasmas, de seus desejos e necessidades”. No mesmo raciocínio, Michaël Safier (1977) defende que as CNs são personificações do poder, uma tentativa enorme de publicar um manifesto ideológico feito de asfalto, concreto e vidro. Para Patrick Boucheron, as CNs não passam de "cidades de fundação e esta fundação é, por definição, um gesto político” (BOUCHERON, 2002, p. 266, tradução nossa). ${ }^{4}$

Nos primórdios, a origem de uma CN esteve ligada à vontade de um príncipe ou de um general conquistador, buscando marcar o tempo e o espaço via a construção de uma cidade representativa e dotada de ordem e de civilização. Curiosamente, isso fica nítido na nomeação dada a algumas, quando o fundador empresta seu nome ao novo núcleo para consubstanciar sua ideia dominante. O diplomata José Osvaldo de Meira Penna menciona tal recorrência em sua obra Quando mudam as capitais:

3 “[...] marque de l'action du pouvoir et de la collectivité depuis l'Antiquité, traduisant le désir des hommes de construire leur propre ville à la manière de leurs idéaux et fantômes, de leurs désirs et de leurs besoins [...]"

4 “[...] villes de fondation et cette fondation est, par définition, un geste politique [...]” 
Akhetaton está indissoluvelmente ligada à memória de Akhenaton, o faraó herege [...]. Alexandria, capital do Egito ptolomaico, foi a mais ilustre das metrópoles que o conquistador macedônio Alexandre espalhou a granel, no passo de suas conquistas extraordinárias pela Ásia ocidental. Bizâncio, consagrada como a Segunda Roma, perdeu o nome de seu fundador, Bysas, para receber o de Constantino. São Petersburgo é a cidade de Pedro, o Grande. (PENNA, 1958, p. 26)

Figura 7: Karlsruhe

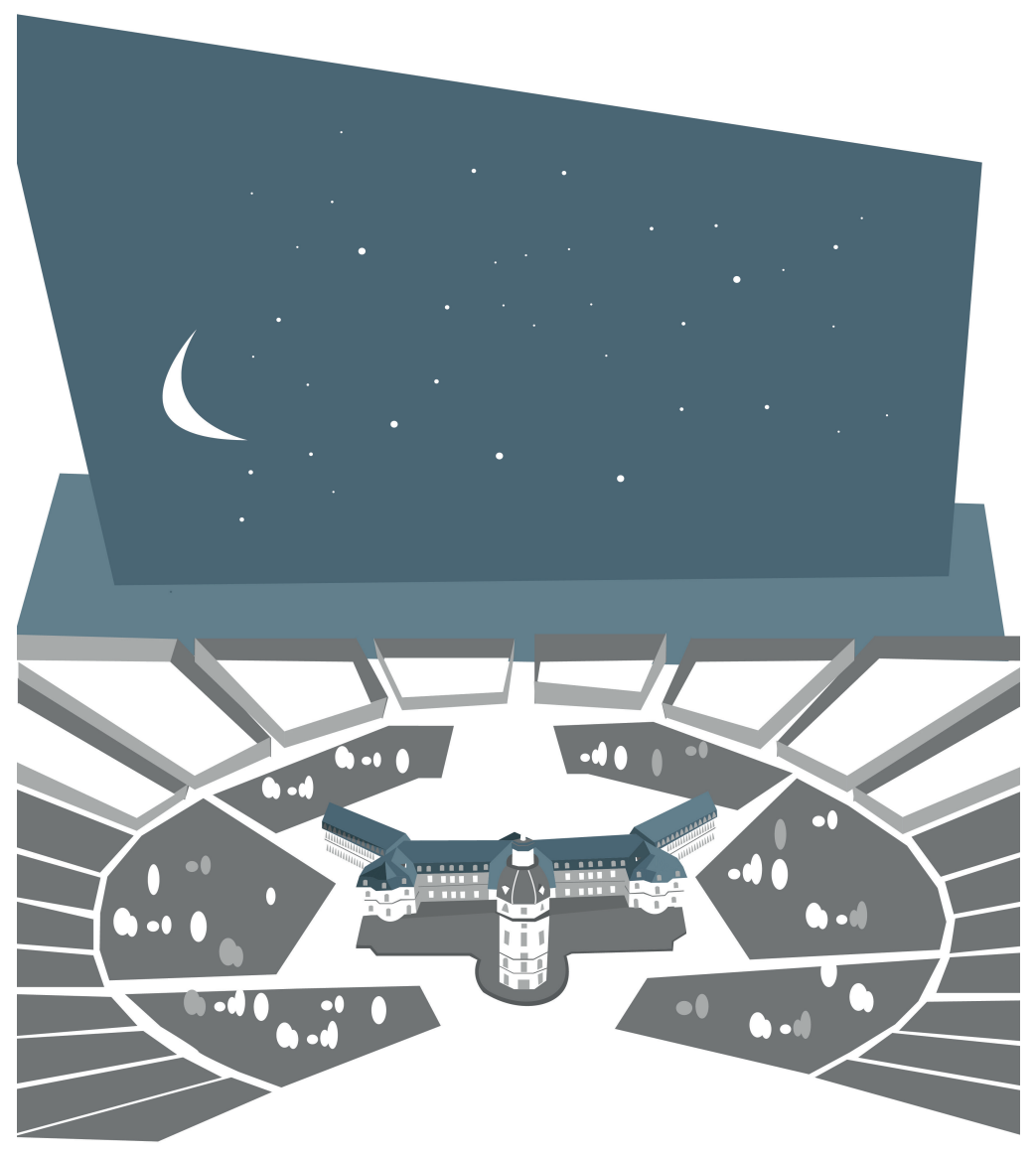


No absolutismo europeu do século XV ao XVIII, poder e CNs são novamente associados. O urbanismo e a arquitetura monumentais de Versalhes na França (1664) ou de Karlsruhe na Alemanha (1715) expressam realisticamente a força monárquica desse período. O artifício patte-d'oie - três vias confluentes, neste caso, para a entrada do castelo - foi aplicado para estruturar e organizar ambos os assentamentos, um traçado de vias cujo enquadramento foi garantido por edificações com gabarito e fachadas normatizadas. Um cenário meticulosamente projetado a fim de simbolizar o poder soberano (PANERAI; GENDRE; CHATELET, 1986).

Em tempos modernos, a simbologia de poder no tecido urbano das CNs é posta em prática mediante duas possibilidades: uma pautada na fundação de inúmeras cidades visando à ocupação de um território, demonstrando domínio - posse - sobre ele; a outra, direcionada à criação de novas capitais, sedes administrativas de uma região ou de um país.

A primeira possibilidade engloba uma escala mais abrangente, necessariamente envolvendo uma política de planejamento regional (MERLIN apud BOUMAZA et al., 2006), cujo objetivo primordial é ocupar e colonizar terras ermas, a exemplo do ocorrido no Brasil com a política pombalina a partir do século XVIII e as ações na franja pioneira paulista e paranaense durante o século XX. É em cenários assim que o setor privado - cooperativas, empresas, companhias, ou mesmo indivíduos ricos -, sustentado por iniciativas do poder público, aplicará seu capital na fundação de cidades - de tentativas isoladas a parcerias com órgãos estatais em políticas de desenvolvimento e integração nacional, o espectro de atuação do setor privado qualifica-o como um dos principais agentes responsáveis pela construção de novos assentamentos.

Já a segunda possibilidade, passível de enquadramento numa política de planejamento regional, ocorre pontualmente na figura de CNs administrativas, símbolo do poder e da ordem de uma região (GORDON, 2006), como em Minas Gerais (Belo Horizonte, 1893), em Goiás (Goiânia, 1933), em Roraima (Boa Vista, 1944), nos estados indianos de Punjabi e Haryana (Chandigarh, 1952), em Tocantins (Palmas, 1989), ou em uma nação, como fica exemplificado nas novas capitais dos Estados 
Unidos da América (Washington, 1791), da Austrália (Canberra, 1908), da Turquia (Ankara, 1923), Índia (Nova Délhi, 1929), Paquistão (Islamabad, 1958), Nigéria (Abuja, 1976), Costa do Marfim (Yamoussoukro, 1983) ou Cazaquistão (Astana, 1997). Seja qual for a escala de abrangência, tais cidades tornam-se representações de uma visão uniforme dos princípios de ocupação do espaço, refletindo, em seu traçado e em sua arquitetura, o poder sobre elas estabelecido.

Economicamente, as CNs servem como instrumentos de multiplicação do capital. São tidas como investimentos diretos e indiretos na obtenção de lucros por seus empreendedores. Diretos, quando são planejadas para a comercialização da terra recém-urbanizada; indiretos, quando esses núcleos servem apenas de base para outras atividades econômicas - exploração de jazidas minerais, por exemplo. Nesse sentido, as CNs são consideradas como respostas otimistas a períodos particulares de desenvolvimento (CHALINE, 1985), como soluções para catástrofes ambientais (ROUAT, 1996), como abrigos para refugiados de guerras (AGIER, 2001) ou como ações políticas de desenvolvimento econômico e de planejamento de todo o território nacional em países em desenvolvimento (MERLIN, 1977).

No geral, os motivos de conjuntura política e econômica despertam em indivíduos, sejam eles da esfera pública, privada ou de ambas - em parceria -, o querer, a intenção, o desejo em criar cidades. Cidades como produtos bem particulares das condições de lugar, de tempo, dos meios de ação pública e privada e, enfim, da presença de uma clientela socioeconômica, como salientam Jackie Poitevin, Bernard Etteinger e Gilles Antier (1993).

São produtos com a marca de seu produtor. Vejam-se: 1) Washington (1791), cujo obelisco central do Mall comemora o general George Washington (1732-1799), vitorioso e estadista austero a quem os Estados Unidos da América devem sua independência; 2) Pretória (1860), a capital administrativa da República da África do Sul, que celebra Andries Wilhelmus Jacobus Pretorius (1798-1853), o maior bandeirante bôer; 3) Marília (1923), no estado de São Paulo, cujo nome provém de uma regra da Companhia Paulista de Estradas de Ferro em nomear seus ramais (cidades) por 
ordem alfabética; 4) Londrina (1929), uma referência a Londres feita pela empresa de capital inglês Companhia de Terras Norte do Paraná; 5) Junqueirópolis (1945), a CN paulista que recebeu o sobrenome de seu empreendedor, Álvaro de Oliveira Junqueira; e 6) Sinop (1974), no estado do Mato Grosso, sigla para Sociedade Imobiliária do Noroeste do Paraná, responsável pela sua construção. CNs cujos nomes são testemunhos de suas criações, fazendo referências diretas a seus criadores.

\section{Poder público e suas cidades novas}

Uma CN, segundo a definição do arquiteto Ervin Y. Galantay, é uma comunidade planejada e conscientemente criada como resposta clara a objetivos estatais. Tal criação urbana pressupõe, parafraseando o arquiteto, a existência de uma autoridade ou uma organização suficientemente poderosa para assegurar o sítio - recursos primários para seu desenvolvimento - e para exercer controle contínuo até que a cidade atinja tamanho viável (apud WEINER, 1981, p. 394).

A realização de CNs é uma operação pesada - infraestrutura, logística, capital envolvido etc. -, que demanda do Estado e seus órgãos competentes um trabalho de planejamento, de execução e de monitoramento. Para Pierre Bloc-Duraffour (1998), será o Estado o responsável por: fixar um quadro legislativo, que prevê o financiamento e aprova o plano; definir os projetistas; incluir operadores privados; e oferecer o título de município ao recém-inaugurado assentamento.

Além das ações previstas no processo, o Estado age em tempos precisos da história em função de necessidades momentâneas. Foi assim na França durante a Guerra dos Cem Anos com a Inglaterra (1337-1453). A disputa por terras continentais levou a monarquia francesa a pulverizar centenas de bastides (cidadelas fortificadas) em sua costa oeste; mesma ação adotada pelos ingleses ao conquistar terras francesas. As bastides eram pequenos núcleos regularmente traçados ao redor de uma praça, que, além da função defensiva, serviam como entrepostos comerciais (PANERAI et al., 1985). 
A conquista por território - defesa de fronteiras, colonização de regiões desabitadas, expansão agrícola etc. - também foi uma preocupação estatal na primeira metade do século XX: veja-se a “Marcha para o Oeste” de Vargas (1930-1945). Governos de diversos países convergiram esforços para o planejamento do território a partir de um ou vários projetos especiais, divididos em quatro categorias por Michaël Safier (1977):

1. programas de planejamento rural (repartição de serviços que auxiliem o planejamento de comunidades rurais e melhoramento da agricultura);

2. programas de planejamento de recursos regionais (infraestrutura necessária para a execução de grandes projetos visando a uma exploração futura, como hidroelétrica ou jazida mineral);

3. programas de planejamento industrial (implantação equilibrada sobre o território); e

4. programas de planejamento urbano (descentralização das atividades presentes nas grandes cidades em favor de uma rede mais racional na repartição de empregos, moradias, equipamentos e meios de transportes).

Para o autor, "cada um destes programas governamentais deu origem a uma cidade nova bem particular” (SAFIER, 1977, p. 4, tradução nossa) ${ }^{5}$ - cidades empreendidas por um Estado totalitário e centralizador, como na URSS de Stálin (1922-1953), na Itália de Mussolini (1922-1943) ou na Espanha de Franco (19361975); ou por um Estado provedor e desenvolvimentista, como nos Estados Unidos da América de Roosevelt (1933-1945). Em ambos os casos, as CNs tornaram-se instrumentos criados em razão de ações políticas.

Na União das Repúblicas Socialistas Soviéticas (1922-1991), a organização da planificação urbana foi fundada pelo poder central sobre a articulação de planos em diferentes escalas, coordenados e impulsionados pelo Gosgrajdanstroj ou GOSSTROI - espécie de Ministério da Construção. Este dispôs institutos de pesquisa 5 “[...] chacun des programmes gouvernementaux a donné lieu à une nouvelle ville très particulière [...]” 
e de planificação em cada uma de suas Repúblicas. A localização precisa de cada CN era determinada pela direção de planejamento do território em acordo com órgãos locais de administração. Cada CN teria seu próprio Plano Diretor, estabelecido por um dos institutos e aprovado pelo Comitê de Estado para Construção (MERLIN, 1992).

Essa política foi conduzida por duas preocupações gerais, ambas atreladas a questões econômicas. De um lado, buscava-se harmonizar a repartição da população em função da natureza dos recursos e disponibilizar, ao mesmo tempo, um bom número de serviços, em que a "elaboração de um esquema geral de povoamento da URSS seria a verdadeira chave para o desenvolvimento e para criação de aglomerações” (BEAUJEU-GARNIER et al., 1982, p. 732, tradução nossa). ${ }^{6}$ Por outro lado, pretendia-se: evitar a anarquia do crescimento urbano, limitando o tamanho das grandes cidades; desenvolver a industrialização, sobretudo em pequenas e médias cidades; e preservar o meio rural, favorecendo empregos para jovens no local. Com isso, o governo stalinista conseguiu aplicar, dentre outros procedimentos, a regulação pública da terra, a indústria socialista da construção, a supremacia de investimentos públicos no setor imobiliário e o controle do estoque de moradia (BERNHARDT, 2005b). Uma fórmula que o governo soviético transpôs para países sob sua custódia na Europa Oriental - Polônia, Hungria, Bulgária, Alemanha etc. -, visionando explorar recursos naturais pela criação de inúmeras cidades.

Na Alemanha socialista (1949-1990), as CNs, embora empreendimentos privados, surgiram a partir de uma política pública soviética de consolidação industrial. Apresentavam, no geral, duas grandes particularidades: 1) base para construção de grandes indústrias, sendo "laboratório experimental para um sistema histórico de governo” (BERNHARDT, 2005a, p. 127, tradução nossa); e 2) estudo para a transformação de áreas agrícolas - onde uma classe burguesa ainda se fazia presente - em áreas industrializadas. Dentre as CNs

6 “[...] élaboration d'un schéma général de peuplement de U.R.S.S. qui est la véritable charte pour le développement et la création des agglomérations." 
alemãs, encontram-se quatro exemplares, todas empresariais e construídas por seus empresários: Stalinstadt (1951), atual Eisenhüttenstadt, erguida pela empresa Complexe Sidérurgique J.W. Stalin/Est; Hoyerswerda (1957), ligada ao complexo energético de Schwarze Pumpe; Schwedt (1959), ligada ao complexo petroquímico PCK - Petrochemisches Kombinat; e Halle-Neustadt (1964), construída para operários da indústria química, com previsão de atender a 70 mil habitantes - a maior de todas.

Na Itália (1922-1945), o movimento de urbanização territorial fascista começou pela aplicação de uma política antiurbana, traduzida pela prática da tabula rasa. O objetivo era venerar o novo regime e apagar todo traço da época precedente, construindo cidades conforme o ideal mussoliniano (VALLAT, 2001). Oficialmente, o objetivo dessa campanha antiurbana estava em racionalizar a utilização de uma mão de obra abundante dentro do território nacional, além de se transformar em um instrumento de propaganda do governo do Duce.

Os governantes fascistas trabalharam para disponibilizar uma bonificação agrícola capaz de animar regiões até então pouco habitadas e de promover uma industrialização economicamente eficaz. Para isso, necessitou apoiar-se sobre o planejamento do território, ou seja, visionar um desenvolvimento equilibrado do país. Para Donata Pizzi (2004), surgiram apenas 37 novos assentamentos; para Giorgio Pellegrini (2006), foram 137 novos villagios e borgos (aldeias), implantados entre 1922 e 1943 em várias regiões da Itália, dentre os quais se destacam: Mussolinia (1924), Sabaudia (1933), Aprilia (1936), Guidonia (1937) e Fertilia (1939).

Na Espanha de Franco (1938-1973), os nuevos pueblos planejados no Instituto Nacional de Colonização foram implantados sobre territórios até então inóspitos - zonas secas, alagadiças e subdesenvolvidas. A política de ocupação do governo franquista, financiada pelo Banco Central espanhol, iniciou por preparar os terrenos - programas de irrigação e drenagem, redes de serviço e sistema de estradas -, passando ao planejamento dos novos centros urbanos - desenhos inspirados nas 
cidades da América espanhola: quadrícula com a plaza central - e fechando com a instalação de infraestruturas necessárias ao desenvolvimento dessa nova rede urbana.

Contrapondo-se aos governos ditatoriais, a gestão democrática do presidente Franklin Delano Roosevelt (1882-1945), nos EUA, apresentou seu pacto de recuperação da crise econômica de 1929 no plano New Deal (1933-1937). Nele, encontramos especificamente o programa do Greenbelt towns, um sopro de planejamento nacional que incluiu a construção, entre 1935 e 1938, de três CNs: 1) Greenbelt (1935), localizada no estado de Maryland, entre Washington e Baltimore, criada para acolher funcionários públicos da capital americana; 2) Greenhills (1936), situada no estado de Ohio, próxima a Cincinnati; e 3) Greendale (1936), implantada no estado de Wisconsin, perto de Milwaukee - as duas últimas construídas para abrigar operários e minorias sociais (STEIN, 1989).

Numa escala menos ambiciosa que os programas europeus, as três greenbelt new towns foram concebidas como programas pilotos de economia cooperativa, conservação de terras e moradias a baixo custo (EDEN; ALANEN, 1983). Esse planejamento social e ambiental de CNs norte-americanas foi adotado, em parte, para atingir metas sociopolíticas, como acesso a moradias de qualidade - num total de 2,2 mil moradias construídas - e revitalização da economia regional. Todas eram controladas pelo poder público e dispunham de uma maior participação comunitária nas tomadas de decisões. O programa, porém, teve vida curta e as CNs foram tomadas por agentes privados a partir de 1954.

Após a Segunda Guerra Mundial, governantes ao redor do globo se beneficiaram das CNs como mecanismos de controle de crescimento das grandes cidades e como espaços destinados a resolver déficits habitacionais e empregatícios. New towns, villes nouvelles, cidades-satélites fervilharam pelas vizinhanças de metrópoles sob o comando atento do Estado.

Tendo o New Town Act (1946) da Inglaterra como ponto de partida mundialmente reconhecido, “baseado no suporte compreensivo do poder público” (WALKER, 1994, 
p. 7, tradução nossa), ${ }^{7}$ o movimento de cidades-satélites logo atravessou o Canal da Mancha e aportou no continente.

A política francesa de CNs nasceu da reflexão animada por Paul Delouvrier (1914-1995), inspetor de finanças, depois de pedido feito pelo presidente Charles de Gaulle no início dos anos 1960. Ao sobrevoar de helicóptero a região parisiense, de Gaulle pediu: “Delouvrier, mettez-moi de l'ordre dans ce bordel” (Paul Delouvrier, coloque-me ordem neste bordel), referindo-se ao caos no qual a periferia parisiense se encontrava (VADELORGE, 2005, p. 8).

O então primeiro-ministro Georges Pompidou (1911-1974), em diretrizes passadas a Paul Delouvrier em abril de 1966, exigiu a elaboração de um esquema diretor de planejamento da Grande Paris e de um esquema estrutural para as demais metrópoles francesas - Lion, Marselha, Lille etc. A solução encontrada foi a criação de CNs num esforço de humanizar, ordenar e controlar os movimentos de urbanização. A partir de cinco cidades-satélites na região parisiense e quatro próximas a cidades do interior Val-de-Reuil em Rouen; Lille-Est (ou Villeneuve d’Ascq) em Lille; Rives de l'Etang de Berre em Marselha; e L'Isle d'Abeau em Lion -, o programa sugeriu “um plano de conjunto, com articulação coerente entre diferentes bairros, tipos de arquitetura, diversidade de habitações, situadas ao redor de um centro atrativo e moderno [...], oferecendo a seus habitantes possibilidades de emprego, lazer e desenvolvimento cultural” (ROULLIER, 2004, p. 24, tradução nossa). ${ }^{8}$ Com isso, o governo francês pretendia:

[...] frear o desenvolvimento da mancha urbana de Paris, canalizando a urbanização em áreas definitivas, situadas na periferia e interligadas à capital por estradas tangenciais sem perpassar a região central; e evitar nestas áreas os fenômenos de periferização e da formação de cidades-dormitórios, pela criação de um verdadeiro

7 "[...] based on the comprehensive support of public power [...]"

8 "[...] un plan d'ensemble, assureront l'articulation cohérente de quartiers variés, de types d'architecture et d'habitation différentes autour d'un centre attractif et moderne [...] apporter à leurs habitants les possibilités d'emploi, de loisirs et de développement culturel." 
e próprio centro urbano, dotado de habitação, serviço e postos de trabalhos. (BERTUGLIA; TICH; STANGHELLINI, 2004, p. 12, tradução nossa). ${ }^{9}$

Portanto, o plano de CNs francesas foi o desejo estatal de planejar o território e a necessidade de melhor estruturar o desenvolvimento da aglomeração parisiense e das grandes metrópoles do interior (SUDOUR, 1987).

Da Inglaterra ou da França, onde tal política de urbanização tomou corpo, o uso de CNs como controle da expansão urbana sob comando estatal difundiu-se por outros países da Europa assim como para outros continentes.

Na Dinamarca, a vontade política de frear o crescimento de sua capital gerou o "Plano dos Dedos" (1963): da palma (Copenhague) sairiam cinco dedos linhas férreas - para a periferia e propostas cinco CNs, dentre elas, Albertslund (1963), a primeira a ser construída e projetada para 40 mil habitantes (HELAND, 2005). Política similar adotada pelo governo socialista sueco para sua capital, Estocolmo, cujos arredores foram tomados por inúmeras CNs, como Vällingby (1950) (BOUCHER-HEDENSTRÖM, 2005). Na Espanha pós-franquista, o ministro da Habitação, Vicent Mortes Alfonso, propôs o ACTUR (Actuations Urbanica Urgentes) nos anos 1970, que consistia em criar um amplo número de moradias, independentemente do processo de desenvolvimento, por meio de CNs erguidas no entorno de grandes cidades e livres de restrições locais de planejamento (CARRERAS, 1986). Nos arredores de Barcelona, três CNs da ACTUR foram propostas num raio de 15 a 20 quilômetros, sobre terras virgens, com previsão de 150 mil pessoas cada.

9 “[...] per frenare lo sviluppo dello spot urbano di Parigi, canalizzando l'urbanizzazione in aree definitive, situate nella periferia e interconnesse alla capitale attraverso strade tangenziali senza attraversare la regione centrale; ed evitare in queste aree i fenomeni di perifericizzazione e formazione di dormitori cittadini, con la creazione di un vero e proprio centro urbano, dotato di alloggi, servizi e postazioni di lavoro." 
Na Ásia, o empreendedorismo estatal para criar CNs esteve presente no Japão, na Coreia do Sul, em Hong Kong, em Cingapura, na Tailândia, na Índia, no Irã, sem mencionar dezenas e dezenas de exemplares empreendidos pelo governo chinês no século XXI.

Na terra do sol nascente, a participação de órgãos ligados ao governo, envolvidos com questões relacionadas à habitação e ao desenvolvimento urbano, é um dos exemplos mais nítidos do desejo público em efetivar CNs. Exemplo disso é a cidade-satélite de Tama (1965), concebida pela Corporação de Desenvolvimento Habitacional e Urbano e implantada nos arredores de Tóquio (DUCON; YOKOHARI, 2006). Na vizinha Coreia do Sul, o governo lançou, em fins dos anos 1980, um plano para a construção de 2 milhões de habitações, efetivado a partir da construção de cinco CNs nas cercanias de Seul: Bundang, Ilsan, Pyeongchon, Sanbon e Joongdong (LEE; AHN, 2005).

No sudeste asiático, as propostas surgidas foram similares. Em Hong Kong, o programa de CNs previa oferecer 1,8 milhões de moradias em nove CNs (HUI; LAM, 2005); em Cingapura, as CNs de Bukit Batok e Bishan foram resultados de programas públicos de habitação para massas (ENG, 1996); e, na Tailândia, as políticas de desconcentração industrial de Bancoc e de habitação, durante os anos 1970, promoveram o surgimento de CNs, como Bang Plee (1978), cuja preocupação era buscar um equilíbrio entre moradia e emprego, condição primordial de autonomia de uma cidade nova (BARON, 1992).

Na Índia, o governo, dentre as inúmeras políticas de desenvolvimento, preocupou-se em afastar as novas indústrias de grandes e congestionadas cidades, ao considerar: o conceito de região; o planejamento de áreas urbana e rural de modo associado; e a ocupação do campo com uma diversidade de produção para garantir a independência da região (PRAKASH, 1969). Desde a Independência, em 1947, mais de 30 CNs foram construídas na Índia. Primeiro com as cidades administrativas - Nova Délhi e Chandigarh - ou com cidades para abrigar refugiados vindos do Paquistão. Em 1951, com o plano quinquenal, novas cidades surgiram em áreas de projetos de irrigação, drenagem e de energia. Posteriormente, a ênfase passou para 
CNs industriais como apoio a usinas. Com isso, as CNs indianas foram utilizadas pelo Estado como modo planejado de dispersão da população centralizada nas grandes cidades e como instrumento de desenvolvimento econômico.

Assim, percebemos um tipo de urbanismo adotado por diferentes culturas, em realidades diversas. Um tipo urbanístico que não encontrou barreiras nem preconceitos, sendo adotado tanto por países liberais do ocidente como por países islâmicos do oriente, cito Irã e Argélia, onde as CNs foram utilizadas como estratégia política para descongestionar as grandes cidades.

No país norte-africano, a política de CNs surgiu como resposta a um duplo problema: acolher a população da capital Argel, como fez a CN de Badjarah-Ouchaya (1958), e dinamizar regiões pobres. Já as CNs de Roche Noir - atual Boumerdès - e de Aïn Oussera surgiram no início da década de 1960 como cidades administrativas, pretexto de novos governantes para marcar simbolicamente sua independência da França em 1975 (JOSSIFORT, 2000). Ainda nos anos 1970, o COMEDOR - Comitê Permanente de Estudos de Desenvolvimento, de Organização e de Planejamento da Aglomeração de Argel - previu a criação de polos urbanos dinâmicos, organizados em arcos - quatro coroas - ao redor da capital argelina. As CNs foram organizadas em dois grupos: o primeiro deveria descongestionar as metrópoles litorâneas pela implantação de polos urbanos nas $1^{\mathrm{a}}$ e $2^{\mathrm{a}}$ coroas - CNs com funções para turismo ou centros de pesquisa e tecnologia; o segundo teria por objetivo acompanhar a valorização de regiões do alto platô e do sul argelino, como a CN de Boughzoul.

Por fim, além das políticas de ocupação territorial e controle da urbanização existente, os governos de países em desenvolvimento assumiram a criação de CNs visando à exploração de recursos minerais, verificável no Brasil dos anos 1950 a 1980 - como veremos no início dos capítulos 2 e 6 - e em países da África.

Contemporânea a Beida (1965), na Líbia, visionada para ser o maior centro administrativo do país, e a Kafue (1966), na Zâmbia, cuja função era atrair população da capital Lusaka e criar um novo polo industrial - ambas projetadas pelo escritório grego Doxiadis Associates (DOXIADIS ASSOCIATES 
INTERNATIONAL, 1971) -, temos a CN de Malbaza (1967), na Nigéria. Nesse caso particular, o objetivo do governo nigeriano era possuir, em seu território, uma usina de cimento para fomentar a industrialização do país, criar novos empregos e diminuir as importações.

Setor privado e suas cidades novas

Com atuação em conjunto com órgãos estatais ou por iniciativa isolada, as ações do setor privado em prol do surgimento de CNs vão ser recorrentes, particularmente após a Revolução Industrial, graças à presença de capital excedente nas mãos de indivíduos e de sociedades empresariais.

Antes do aparecimento das indústrias, a Europa já apresentava exemplares de CNs privadas. Segundo Olivier Zeller (2003), na Polônia e na Ucrânia dos séculos XVI e XVII, CNs foram fundadas por iniciativa de famílias nobres como apoio à comercialização de produtos agrícolas - por exemplo, a CN polonesa de Ulanow, de 1616. Essas pequenas cidades (agrovilas) tinham uma escala menor que as cidades reais, com apenas um elemento que as caracterizava como urbana: a presença do mercado, devendo seus moradores respeitar as regras estabelecidas pelo dono da cidade. Algo semelhante ocorreu na Irlanda do século XVIII com as landlord towns, frutos de uma política de remodelação da geografia daquele país bem como do intuito de promover fundações de cidades com espaços culturais que reforçassem a dominação anglicana.

No berço da indústria moderna, Inglaterra, as CNs privadas assumiram a figura de company towns e datam da segunda metade do século XVIII (SICA, 1981 e CREESE, 1992). Porém, foi a partir de meados do século XIX que surgiram significativos projetos de cidades ou vilas empresariais: um tipo cuja origem estava relacionada à criação de indústrias em áreas não assentadas, que dispunham de recursos naturais - bens primários, energia natural gerada por água, minas de carvão etc. - para a produção, melhoria das condições de vida e disciplinamento da mão 
de obra industrial. Entre os assentamentos ingleses financiados por capital privado estão: Copley (1847), Saltaire (1851), Akroydon (1859), Bournville (1879) e Port Sunlight (1888).

Quase que simultaneamente às company towns, surgiram as cidades recreativas - empreendimentos lucrativos para inúmeras sociedades e grupos financeiros que se apoderavam de áreas ambientalmente interessantes - praias, montanhas, reservas de aquíferos termais - em busca de lucro pela renda imobiliária. Em muitos casos, essas indústrias sem chaminés tornavam-se renda de monopólio uma vez que a oferta era quase irreprodutível. Os empreendedores também foram beneficiados pela ajuda de Estados, que incentivavam a exploração e o desenvolvimento desse setor da economia.

Na Inglaterra, aglomerações surgiram com finalidade recreativa: as estâncias termais de Buxton (1780) e Cheltenhan (1800); as litorâneas Brighton (1820, de iniciativa privada da empresa Cliff Bridge Company), e Bournemouth (1835).

Esse grupo de cidades inglesas, projetadas e planejadas para atender a uma determinada função - lazer e saúde - por meio de elementos urbanísticos ou da presença de edifícios especializados - balneário, hotéis, cassino -, criou raízes não apenas em território britânico como saltou ao continente europeu e americano, ${ }^{10}$ atraindo interesses de investidores privados.

Além desses tipos de investimentos, o setor privado, no século XX, direcionou sua atenção para a exploração de recursos minerais, visando à fomentação da indústria primária. No continente africano - cujo subsolo é rico em recursos naturais (petróleo, urânio, ferro, ouro, diamante, fosfato) -, a criação de CNs esteve diretamente relacionada ao desejo de certos financistas engajados na exploração dessas riquezas. Para A. Moussa (1972), as CNs africanas surgiram como um disfarce luxuoso para a forma de exploração que ainda continua desde o período

\footnotetext{
${ }^{10}$ Outros exemplos de cidades balneárias: Alemanha (Baden-Baden e Marienbad); Áustria (Josefplatz, Badgastein e Bad Ischl); Bélgica (Ostende e Spa); Espanha (San Sebastián); França (Deauville, Canche e Vichy); Holanda (Scheveningen); Suíça (Carlsbad, Davos, Grindelwald, Zermatt e St. Moritz); Estados Unidos da América (Saratoga Springs, Lenox, Colorado Springs, Newport e Miami); e Brasil (Guarujá, Campos do Jordão, Águas da Prata, Águas de São Pedro, Araxá etc.).
} 
da colonização. Seus empreendedores eram sociedades mineradoras e industriais estrangeiras, cuja “preocupação maior não é [era] de ser ‘bons apóstolos’ para a população, mas de explorar um grande benefício a custo baixo” (MOUSSA, 1972, p. 6, tradução nossa). ${ }^{11}$ Dentre as CNs africanas de iniciativa privada, temos: Tema (1952), em Gana, empreendida pela Tema Development Corporation; e Gamba (1969), no Gabão, patrocinada pelo grupo petroquímico da Shell. Hoje, a presença de capital chinês em países detentores de reservas petrolíferas é reconhecida, contribuindo para o aumento de CNs naquele continente.

Particular vai ser o caso norte-americano. Após a independência em 1776, houve uma reação, liderada por promotores privados e especuladores, contra o planejamento realizado por autoridades governamentais sobre a localização das cidades. O objetivo era deixar o número e a distribuição dos núcleos urbanos à mercê da força do mercado, garantindo, assim, a obtenção de benefícios e lucros num sistema de livre concorrência (HAMER, 1994). Desse modo, enquanto os empreendedores procuravam terrenos livres, sobretudo aqueles presentes em eixos de crescimento, longe das aglomerações existentes, o Estado apenas participava das questões financeiras e de implementação de infraestruturas.

Os exemplos de CNs norte-americanas como empreendimentos privados percorrem desde o planejamento Mórmon de cerca de 350 cidades no oeste do país entre 1847 e 1877, como Salt Lake City (1847), passando por cidades empresariais fechadas, como Pullman (1880) e Hershey (1897) (BLOOM, 2005), até CNs empresariais da segunda metade do século XX, como: Mission Viejo (1963), ligada à empresa Philip Morris; Woodlands (1969), empreendida pela Woodland Development Corporation, uma filial da Mitchell Energy and Development Corporation (LOEVENBRUCK, 1986).

Já na Austrália, entre 1770 e 1830, a maioria das iniciativas de fundar e planejar cidades cabia ao Estado, particularmente ao governo inglês. A partir daí, esse

11 “[...] la préoccupation n'est pas d'être de « bons apôtres » pour la population, mais d'exploiter un grand avantage à faible coût.” 
papel foi dividido com agentes privados, incluindo companhias colonizadoras (HAMER, 1994), principalmente na promoção de cidades secundárias para empresas privadas. Como exemplos, South Australia (1835), fundada por uma companhia fortemente influenciada pelas teorias colonizadoras de Edward Gibbon Wakefield, ${ }^{12}$ e Melbourne (1838), uma das primeiras cidades modernas a se utilizar do cinturão verde como controle de expansão territorial e locação de equipamentos urbanos.

Atualmente, na Inglaterra, casos envolvendo capital privado e construção de cidades ainda acontecem. O surgimento de novos assentamentos no sudeste britânico e na região de East Anglia são ações de grupos de construtores habitacionais e outros agentes desenvolvimentistas privados. Já para o entorno de Londres, foram propostas de três a quatro CNs com 75 mil a 100 mil habitantes. Trata-se de "uma resposta inevitável ao processo de descentralização das grandes cidades para pequenos assentamentos ou áreas rurais; ou um novo modo de pensar a mudança de áreas dinâmicas economicamente no Reino Unido” (HERINGTON, 1988, p. 308, tradução nossa). ${ }^{13}$

Seja por empreendedores do setor privado ou do poder público, enfim, o panorama apresentado nos coloca em contato direto com o primeiro atributo caracterizador de CNs na metáfora aqui empregada, isto é, o primeiro segmento do seu DNA. O desejo em criar cidades nos revela a importância do agente desejador bem como os frutos deixados por tal ação - CNs surgidas nos quatro cantos do planeta a fim de suprir uma vontade e, necessariamente, uma função, como posto a seguir.

12 O político inglês Edward Gibbon Wakefield (1796-1862) foi responsável por criar um planejamento de colonização da Austrália, que atraía imigrantes do Reino Unido pela oferta de trabalhos e terras. Para ele, seria uma válvula de escape para os problemas sociais e para o rápido e descontrolado crescimento das grandes cidades inglesas.

13 "[...] an inevitable answer to the decentralization process of large cities to small settlements or rural areas; or a new way of thinking about changing economically dynamic areas in the UK." 